\title{
Wealth Effects Of Bank Mergers And Acquisitions In Asian Emerging Markets
}

\author{
José A. Pagán, University of North Texas Health Science Center, USA \\ Yun Chu, Robert Morris University, USA
}

\begin{abstract}
Through analysis of stock responses to two different types of banking $M \& A$ deals, specifying $M \& A$ and diversifying $M \& A$, we find that specifying $M \& A$ deals incur positive cumulative abnormal returns (CAR) in both two-day and three-day windows without controlling for firm size. Diversifying M\&A deals incur positive CAR in two different event windows. However, the differences between the two windows are not statistically significant. Contrary to previous studies on M\&A in the banking industry of developed markets, the results of our study indicate that markets do not distinguish among various types of M\&A deals in the banking industry around the date of announcement. Diversifying M\&A generate positive three-day CARs but they are not significantly better than specifying $M \& A$.
\end{abstract}

Keywords: Mergers and Acquisitions; Banks; Asian Emerging Markets

\section{INTRODUCTION}

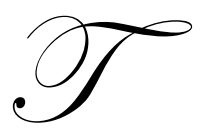

he banking industry is different from other industries in many aspects. First, banks are regulated to reduce the risk of failures that would adversely affect economic activity and possibly create panic in financial markets. Second, the banking sector is characterized by the availability of protection against deposit insurance losses. For example, in the U.S. the Federal Deposit Insurance Corporation (FDIC) represents the depositors' and the public's interests to ensure that banks comply with reserve requirements and reporting provisions. Third, banks are regulated to achieve desired social goals (Fraser et al., 2001). Jackson and Madura (2004) describe the uniqueness of the banking sector as follows:

The commercial banking industry is highly regulated by government-appointed regulators to ensure financial stability. Public trust and confidence in the banking system is critical for an efficient and orderly transfer of capital from depositors to borrowers. However, regulators also restrict managers from expanding into other industries or growing the bank through mergers and acquisitions. By setting limits on financial ratios such as the proportion of highly leveraged loan transactions, regulators attempt to stabilize commercial bank performance. Thus, regulation may impose governance over banks that limit their potential losses (p. 23).

With these unique characteristics and constraints, banks bear risks that are on average far less than those of other industries. Investors may, therefore, expect that regulators will intervene to correct problems before, during, and after M\&A deals occur in the banking industry. Consequently, the market reaction to M\&A deals related to the banking industry should be less pronounced than for other firms. Thus, regulatory differences associated with the financial services industry partly explain why firms with financial service segments (SIC codes between 6000 and 6999) are removed from data samples of many non-banking (or non-financial services) M\&A studies (Berger \& Ofek, 1995; Lang \& Stultz, 1994; Lins \& Servaes, 2002) and discussed specifically in M\&A studies in the banking industry (Delong, 2001, 2003; Dymski, 2002).

Little research has been conducted to empirically assess whether there are any cumulative abnormal return differences between M\&A deals in the non-financial industries and M\&A deals in the banking industry, especially in Asian emerging markets. Unlike developed markets, where market forces play the dominant role to motivate 
M\&A, some Asian governments are instrumental in making such deals happen. For example, some governments encouraged or even forced banking institutions to merge after the 1997 financial crisis (Crouzille et al., 2006; Gelos \& Roldos, 2004; Hawkins \& Mihaljek, 2001; Hawkins \& Turner, 1999). In Malaysia, authorities announced a plan in September 1999 for 54 local banks and financial companies to merge into six large groups (Gelos \& Roldos, 2004). The Singapore government had persuaded the four largest Singapore banks to merge into two so as to ensure their survival as global competitors (Dymski, 2002). These unique M\&A characteristics have attracted some researchers to investigate whether or not market reactions differ between developing and developed markets. On the one hand, the government-sponsored M\&A deals strengthen the banking system and increase competition against foreign banks (Crouzille et al., 2006). Shareholders should gain from the M\&A transactions. On the other hand, a highly concentrated industry could impact regulators and/or influence governments in order to take on more risks (Nicolo et al., 2003). Shareholders might lose from the M\&A transactions. Crouzille et al. (2006) find a significant negative market reaction to the M\&A deals that occurred during the crisis period (1997-2000) and in the less mature banking systems (Indonesia, Malaysia, the Philippines, South Korea, and Thailand). However, whether or not M\&A deals can create value by focusing and/or diversifying bank products remains an open question.

To better understand the valuation effects of M\&A in the Asian banking industry, we present available studies on M\&A in the banking sector in the U.S. and Europe because most focusing and diversifying hypotheses are derived from the U.S. and some other developed economies. Studies on the U.S. banking industry document that, on average, bank mergers do not create value.

Piloff and Santomero (1997) provide an overview of this phenomenon. They find that most studies fail to reveal a positive relationship between merger activity and gains in either performance or stockholder wealth. Their conclusion of no economic benefits on creating value is consistent with the findings from other studies that employ a wide variety of methodologies, samples, and levels of analysis. Piloff and Santomero (1997) also state that there appears to be no relationship between changes in value at announcement and subsequent outcomes. However, exceptions are found in several other studies.

Examining a sample of 107 mergers that took place between 1980 and 1990, Zhang (1995) finds that mergers lead to a significant increase in overall value. Cornett and Tehranian (1992) find that there are significant correlations between stock market announcement-period abnormal returns and the cash flow and accounting performance. Houston et al. (2001) find a positive market reaction to announcements of mergers that are predicted to reduce costs.

Finally, Delong (2001) states that in the US, mergers that focus along geographic and activity lines create value upon announcement. Therefore, a positive relationship between stock returns and M\&A deals does exist under certain conditions.

In Asian emerging markets, few studies have analyzed the relationship between M\&A deals and value effects. One study, however, did such an analysis (Crouzille et al., 2006). By examining the stock market reaction to the announcement of banks M\&A deals in eight East Asian countries over the 1997-2003 period, Crouzille et al. (2006) find a significant negative market reaction to the M\&A deals that occurred during the crisis period (19972000) and in the less mature banking systems (Indonesia, Malaysia, the Philippines, South Korea, and Thailand). Their conclusion raises the questions of whether or not all bank M\&A deals, on average, have a negative significant value effect or if it is possible to distinguish the types of M\&A deals that lead to significant gains from those that do not add value. This issue has been investigated in the U.S. (Delong, 2001) and European countries (Lepetit et al., 2004) but not in emerging markets. Our study investigates the value effects of bank mergers by distinguishing between types of mergers in Asian emerging countries, specifically, mergers classified according to their specialization or diversification.

Our study contributes to existing literature in three ways. First, we compare cumulative abnormal return (CAR) differences between M\&A deals occurring in non-financial industries and M\&A deals occurring in the banking industry. Existing research has not empirically assessed the CAR difference between non-financial industries' M\&A deals and the banking industry's M\&A deals. This analysis is useful to researchers and policymakers interested in understanding why M\&A in the banking industry should be separated from M\&A in non- 
financial industries. Second, our sample construction is more comprehensive than in earlier studies. Our dataset covers more markets (nine Asian emerging markets) and a longer time period (1998 to 2005). The nine Asian emerging markets are Hong Kong, Indonesia, Malaysia, the Philippines, Singapore, South-Korea, India, Taiwan, and Thailand. Third, this study examines the stock market reaction to Asian banking M\&A. Specifically, this study investigates the market reaction to two different kinds of transactions: focusing bank mergers versus diversifying bank mergers. Similar studies (Delong, 2001; Lepetit et al., 2004) have been conducted on the M\&A in the U.S. and the European banking industries, and no examination has focused on developing economies (Nicolo et al., 2003), most likely due to data constraints.

Recognizing whether or not the different types of M\&A can lead to significant gains from those that do not add value is important for several reasons. First, identifying some aspects of mergers that add value helps managers to decide whether and how to create value through M\&A. Second, understanding the possible outcomes of a choice of mergers could be useful in adjusting an investor's portfolio. Third, examining whether or not the focusing and diversifying hypotheses (derived from the U.S. and some other developed economies) could explain M\&A deals in the Asian banking industry.

The rest of the study is organized as follows: Section two introduces the concept of M\&A classification and develops a set of hypotheses; Section three describes the sample data and methodology; Section four presents empirical results; and section five presents conclusions.

\section{CONCEPTUAL BACKGROUND AND HYPOTHESES ON BANKS' M\&A}

\subsection{Classification}

Many studies classify the M\&A deals in the banking industry based on geographic and activity areas of a firm (Delong, 2001; Fraser et al., 2001; Lepetit et al., 2004). A diversifying merger occurs when a bank merges with another bank engaged in different activities or located in markets different from its own. One study of M\&A in the U.S. banking industry classifies mergers in which acquirers and targets are headquartered in different states as geographically diversified (Delong, 2001). To examine activity diversification, Delong (2001) uses Ward's method of cluster analysis and examines the stock market returns in order to classify the bank M\&A deals. His sample is classified into four types: geographic and activity diversification, geographic and activity focus, geographic focus and activity diversification, and geographic diversification and activity focus.

Another study of M\&A in the European banking industry by Lepetit et al. (2004) classifies mergers in which acquirers and targets are headquartered in different countries as geographic diversification, and mergers in which acquirers and targets have different primary business (SIC) codes as product (or activity) diversification. Using SIC code, we classify our sample into two categories: activity diversification and activity specification. Our sample excludes cross-country M\&A transactions, thus we focus on examining the market reaction to activity diversification and activity specification and exclude an investigation of the geographic diversification and geographic specification.

\section{$2.2 \quad$ Hypotheses}

Although the number and size of mergers within the banking industry have steadily increased, there is no clear evidence that banking mergers are economically valuable to shareholders upon announcement. Analyzing both accounting and marketing data for 48 banking mergers over the period 1982-1991, Piloff (1996) finds little change in performance measures and cumulative abnormal returns follows mergers.

Examining the stock market reaction for 123 target banks and 130 bidder banks for M\&A deals that took place during the 1980s, Hawawini and Swary (1990) find that targets do extremely well in M\&A deals. The price of a target bank's shares increases, on average, by about $11.5 \%$ during the week of the merger announcement. The price of the bidding bank stock decreases, on average, during the week of the M\&A announcement, falling generally between $1 \%$ and $2 \%$. 
Houston et al. (2001) analyze a sample of 64 large bank acquisitions (those above $\$ 400$ million in value) over the period 1985-1996. Consistent with the findings of previous research on merger gains, they find that total gains from M\&A are positive, while gains for bidders are negative with target gains being positive.

Regarding the European banking industry, several studies provide evidence that disagree with the conclusions derived from the U.S. market. Examining 54 large M\&A deals of European financial services (not just banks) that took place between 1988 and 1997 in 13 European markets, Cybo-Ottone and Murgia (2000) find that there is a positive and significant increase in value for the average M\&A at the time of the deal's announcement. In addition, they reveal that there is a positive and significant market reaction for the M\&A deals between banks and insurance companies for domestic transactions.

However, those studies do not imply that all bank mergers have an insignificant or a significant value effect, specifically when mergers are classified according to their focus or diversification along the dimensions of activity and geography. Economic theory implies that banks engaging in focusing mergers can create value through economies of scale or reduced overinvestment. Firms engaging in focusing M\&A can take advantage of operating synergies.

According to Delong (2001), the market does distinguish between various types of mergers in the U.S. banking industry. Focusing M\&A, regardless of geographic focus or activity focus, enhance stockholder value by $3 \%$ while the other diversifying M\&A deals do not create value. Examining the stock market reaction to M\&A deals among banks that were announced from 1991 to 2001 in 13 European economies, Lepetit et al. (2004) find that there is a positive and significant market reaction for the two types of transactions: cross-product diversification and geographic specialization.

Crouzille et al. (2006) assess the stock market reaction to the announcement of banks' M\&A deals in eight East Asian countries over the 1997-2003 period by examining 71 transactions. When M\&A deals are classified according to the status of the entity, the time period of the deal, and the maturity of the banking system, they find a negative market reaction to the M\&A deals that occurred during the crisis period (1997-2000) and in the less mature banking systems. Moreover, the market does not differentiate between the target and the acquirer in terms of abnormal returns.

To assess any CAR differences between M\&A in the non-financial industries and M\&A in the banking industry. Therefore, prior to our further analysis on banking M\&A, we hypothesize that:

H1: the CAR differences between the M\&A in the non-financial industries and M\&A in the banking industry is significant.

In Asian emerging economies, even after mergers, many banks need time to deal with bad-loan problems, and their post-merger behavior has often remained tightly constrained. These limits suggest that Asian bank mergers may aim at customer-seeking (or survival-seeking) and not efficiency-seeking (Dymski, 2002). Many protective policies, such as too-big-to-fail, government-led M\&A, make it hard for investors to expect abnormal returns from the specifying M\&A. we therefore, hypothesize that:

H2: There is no abnormal return associated with a specifying M\&A in the banking industry around merger announcements.

Generally, the studies measure the market reaction by calculating a difference between the actual stock price movement on a short-term window (like a three-day window) around the merger announcement and the expected stock price movement. If acquirers obtain no abnormal returns or create firm value through M\&A, why do banks buy other banks? Such behavior is apparently contrary to the stated goal of management to maximize shareholder value. The motivation of management can be explained by a number of hypotheses such as agency cost, hubris hypothesis, and synergy. 
According to Fraser et al. (2001):

The diversifying of financial institutions has been an important force in changing the structure of the financial service industry. The trend is for banks to become a one-stop shopping center for all financial services, offering broker/dealer investment services, insurance products, mutual funds, trust services, and other financial services. Because they are not limited by the same legal and regulatory constraints as banks, they have a significant competitive advantage (p. 17).

If this is true, the stock market should react positively to the diversifying M\&A deals in the banking industry. After examining bank M\&A deals in 13 European countries, Lepetit et al. (2004) document that crossproduct diversification did gain from high expectations for bidding banks.

One possible explanation for bidding firms to earn positive abnormal returns in diversifying acquisitions in emerging economies is that internal capital markets are expected to overcome the information deficiencies of the less-developed capital markets (Hubbard \& Palia, 1999; Stein, 1997). Specifically, internal capital markets play a more important role in less developed countries (Claessens et al., 1999; Shin \& Stulz, 1988). We expect that there are positive market reactions to cross-industry $\mathrm{M} \& \mathrm{~A}$ in emerging markets if firms in emerging economies allocate capital properly in the internal capital markets. Therefore, we hypothesize that:

H3: There is a positive valuation effect associated with a diversifying bank M\&A around merger announcements for the bidding bank.

One stream of studies hypothesizes that, on average, the stock returns of small firms outperform the stock returns of large firms (Berk, 1995; Schwert, 1983). Since diversified firms typically are large firms, they could have lower ex post returns than non-diversified firms because of this size effect (Lang \& Stultz, 1994). We hypothesize that:

H4: There is a significant valuation effect associated with the firm size of the acquirer when a banking M\&A occurs (i.e., bank size matters).

\section{DATA DESCRIPTION AND METHODOLOGY}

\subsection{Data}

We apply the following filters to a preliminary sample that begins on January 1, 1998 and ends on December 31, 2005: (1) The transaction is completed; (2) The acquirer and target are registered in the ten emerging Asian markets (China, Hong Kong, Indonesia, Malaysia, the Philippines, Singapore, South-Korea, India, Taiwan, and Thailand), and the target primary businesses or divisions were located in these markets at the time of transaction; (3) Method of payment for the transactions is disclosed, to limit ourselves to larger M\&A deals. (4) The percent of shares acquired in the deal is $50 \%$ or higher, to focus on significant M\&A deals; (5) The acquirer is a public firm listed on one of the ten Asian emerging markets' stock markets; (6) The acquirer is active and has daily stock price data in DataStream.

The initial dataset of this study has 1,775 transactions. The transactions consist of 439 transactions related to acquirers who are in the financial service industry (SIC codes 6000 to 6999). Acquirers of these 439 transactions consist of banks (SIC code 60XX), credit institutions (61XX), broker and investment advice companies (62XX), insurance companies $(63 \mathrm{XX})$, real estate agencies $(65 \mathrm{XX})$, investment holding companies and real estate investment trusts (69XX). Only the acquirers that are banks are extracted. We find 89 transactions for nine developing markets. China is not in the sample because no transaction is found in the SDC database.

Table 1 indicates that the data distribution by country is uneven. Singapore has two transactions and Indonesia has three. We exclude these two countries from our sample and, as such, only M\&A deals from seven countries (84 transactions) are included in the analyses. However, our statistical analyses generate similar results if we include these two countries (five transactions). 
Table 1: M\&A deals in banking industry of nine markets

\begin{tabular}{lcccc}
\hline \multicolumn{1}{c}{ Nation } & Diversifying M\&A & Focusing M\&A & Total & \% \\
\hline Hong Kong & 2 & 5 & 7 & 13 \\
India & 8 & 5 & 3 & $14.6 \%$ \\
Indonesia & 2 & 1 & $3.4 \%$ & 11 \\
Malaysia & 7 & 4 & 10 & $11.2 \%$ \\
Philippines & 2 & 8 & 2 & $2.2 \%$ \\
Singapore & 1 & 1 & 9 & $10.1 \%$ \\
South Korea & 6 & 3 & 12 & $13.5 \%$ \\
Taiwan & 5 & 7 & 22 & $24.7 \%$ \\
Thailand & 21 & 1 & 89 & \\
\hline Total & 54 & 35 & & \\
\end{tabular}

My sample does not include geographic diversification and/or specification due to few cross-border M\&A deals that occurred in the emerging economies. The transactions are classified as two groups based on their activity. If the acquirer and target are all commercial banks (and share the same 4-digit SIC code), the transaction is withinindustry or focusing $\mathrm{M} \& \mathrm{~A}$; otherwise, the transaction is a diversifying $\mathrm{M} \& \mathrm{~A}$.

\subsection{Methodology}

To examine market reaction to announcement of M\&A deals, we use standard event study methodology and compute market model abnormal returns (see Brown and Warner, 1985). The methodology is based on the assumption that, given rationality in the marketplace, the effect of an event will be reflected immediately in asset prices.

The market model assumes the following linear relationship between the return of any security and the return of the market portfolio:

$$
R_{i t}=\alpha_{i}+\beta_{i} R_{m t}+e_{i t}
$$

Where

$t$ is the time index,

$i=1,2, \ldots, N$ stands for security,

$R_{i t}$ and $R_{m t}$ are the returns on security $i$ and the market portfolio, respectively, during period $t$. The return in the market portfolio is measured by the variation in some benchmarks, such as the Hang Seng Index for the Hong Kong stock market,

$e_{i t}$ is the error term for security $i$.

Equation (1) is estimated over a period that runs between 125 days prior to the event up to 6 days prior to the event. The event window can be defined as a two-day window, a three-day window, or a five-day window. With the estimates of $\alpha_{\mathrm{i}}$ and $\beta_{\mathrm{i}}$ from equation (1), a "normal" return is predicted during the days covered by the event window. The prediction error (the difference between the actual return and the predicted normal return), commonly referred to as the abnormal return (AR), is then calculated from following equation:

$$
A R_{i t}=R_{i t}-\hat{\alpha}_{i}-\hat{\beta}_{i} R_{m t}
$$

Where

$\mathrm{AR}_{\mathrm{it}}$ is the abnormal return for firm $i$ on day $t$, 
$\mathrm{R}_{\mathrm{it}}$ is the actual return for firm $i$ on day $t$.

firms:

Average aggregate abnormal return (AAR) on day $t$ is mean value of summed abnormal returns of sample

$$
A A R_{t}=\frac{1}{N} \sum_{i=1}^{N} A R_{i t}
$$

Our study reports daily AAR from two days before announcement day to two days after announcement day. The AAR is calculated from equation (3). We conduct robust $t$-statistic test and Wilcoxon $z$-statistic test for the significance of AAR.

(CARs):

The daily abnormal returns are summed over the event window to derive the cumulative abnormal returns

$$
C A R_{i\left(T_{1}-T_{2}\right)}=\sum_{t=T_{1}}^{T_{2}} A R_{i t}
$$

Where

$\mathrm{CAR}_{\mathrm{i}}$ is the cumulative abnormal return for firm $i$ over the event window $\left(\mathrm{T}_{2}, \mathrm{~T}_{1}\right)$.

\section{EMPIRICAL RESULTS}

Table 2 indicates that bidder firms experience positive abnormal returns on both non-financial industries and the banking industry. There is no statistically significant difference between two-day CARs for M\&A deals in non-financial industries and in the banking industry. The mean value of two-day CAR in non-financial industries is $1.1 \%$. The mean value of two-day CAR in the banking industry is 0.68 percentage points lower than in non-financial industries. However, the difference is not statistically significant. Regarding three-day window, mean value of CAR increases to $1.43 \%$ in non-financial industries and mean value of CAR in the banking industry is $0.57 \%(=1.43$ 0.86). The difference is statistically significant at the $10 \%$ level. Therefore, H1 (the CAR difference between the M\&A in the non-financial industries and M\&A in the banking industry is significant) is supported at the $10 \%$ significant level. The results imply that the market reaction to M\&A related to the banking industry is less pronounced than for non-financial industries.

Table 2: Valuation effects associated with non-financial industries' $M \& A$ and the banking industry's M\&A A model, CAR $=\beta_{0}+\beta_{1} *$ BANK $+\mathrm{e}$, is used to examine valuation effects associated with non-financial industries' M\&A and the banking industry's M\&A, where BANK is the categorical variable. BANK $=1$ if acquirer is bank, and zero otherwise. CAR is cumulative abnormal return in two-day $(0,+1)$ or three-day $(-1,+1)$.

\begin{tabular}{lcccccc}
\hline \multirow{2}{*}{ Variable } & \multicolumn{3}{c}{ CAR $(\mathbf{0},+\mathbf{1})$} & \multicolumn{3}{c}{ CAR (-1, +1) } \\
\cline { 2 - 7 } & Coeff. & Std. Error & $\mathrm{t}$ & Coeff. & Std. Error & t \\
\hline INTERCEPT & 1.1 & 0.22 & $5^{* * *}$ & 1.43 & 0.25 & $5.85^{* * *}$ \\
BANK & -0.68 & 0.44 & -1.54 & -0.86 & 0.53 & $-1.62^{*}$ \\
\hline
\end{tabular}

The symbols * and *** denote statistical significance at the $10 \%$ and $1 \%$ level, respectively.

When an independent variable, firm size, is added to examine its impact on the CARs, we find no firm size effects on the two-day CAR (see Table 3). However, the firm size is significant at the $10 \%$ level when event window expands to a three-day window. The firm size variable has the expected negative sign, which indicates that large firms have less pronounced market reactions. 
Table 3: Valuation effects associated with firm size

A model, CAR $=\beta_{0}+\beta_{1}{ }^{*}$ BANK $+\beta_{2}{ }^{*}$ SIZE $+e$, is used to examine valuation effects associated with non-financial industries' M\&A and the banking industry's M\&A, where SIZE is measured by the total assets of an acquirer. BANK is the categorical variable. BANK $=1$ if acquirer is a banking firm, and zero otherwise. CAR is cumulative abnormal return in two-day $(0,+1)$ or three-day $(-1,+1)$.

\begin{tabular}{lcccccc}
\hline \multirow{2}{*}{ Variable } & \multicolumn{3}{c}{ CAR $(\mathbf{0},+\mathbf{1})$} & \multicolumn{3}{c}{ CAR $(\mathbf{- 1 , + 1 )}$} \\
\cline { 2 - 7 } & Coeff. & Std. Error & $\mathrm{t}$ & Coeff. & Std. Error & $\mathrm{t}$ \\
\hline INTERCEPT & 1.88 & 0.92 & $2.05^{* *}$ & 2.95 & 0.96 & $3.07^{* * *}$ \\
BANK & -0.008 & 0.69 & -0.01 & 0.4 & 0.78 & 0.51 \\
SIZE & -0.15 & 0.15 & -0.98 & -0.29 & 0.16 & $-1.83^{*}$ \\
\hline
\end{tabular}

The symbols *,**, and $* * *$ denote statistical significance at the $10 \%, 5 \%$, and $1 \%$ levels respectively.

Table 4 reports average daily abnormal returns two days before and two days after the announcement day of the M\&A. Stock markets have positive reactions to mergers and acquisitions around the announcement day. The abnormal return $(0.19 \%)$ on day -1 is higher than the abnormal normal return $(0.04 \%)$ on day -2 . The abnormal return increases from day -2 to day -1 and reaches the highest abnormal return $(0.27 \%)$ on the announcement day. After the event day, abnormal returns decrease to $0.08 \%$ on day +1 but increase to $0.22 \%$ on day +2 . The $t$-statistic indicates that there are no statistically significantly positive abnormal returns around the announcement day. The Wilcoxon signed-rank test indicates that the average abnormal return is significant at the $10 \%$ only on the announcement day. The positive mean CARs of the three event windows: $(0,+1),(-1,+1)$, and $(-2,+2)$, are not statistically significant.

Table 4: Daily abnormal returns and CARs for selected windows in response to M\&A announcement

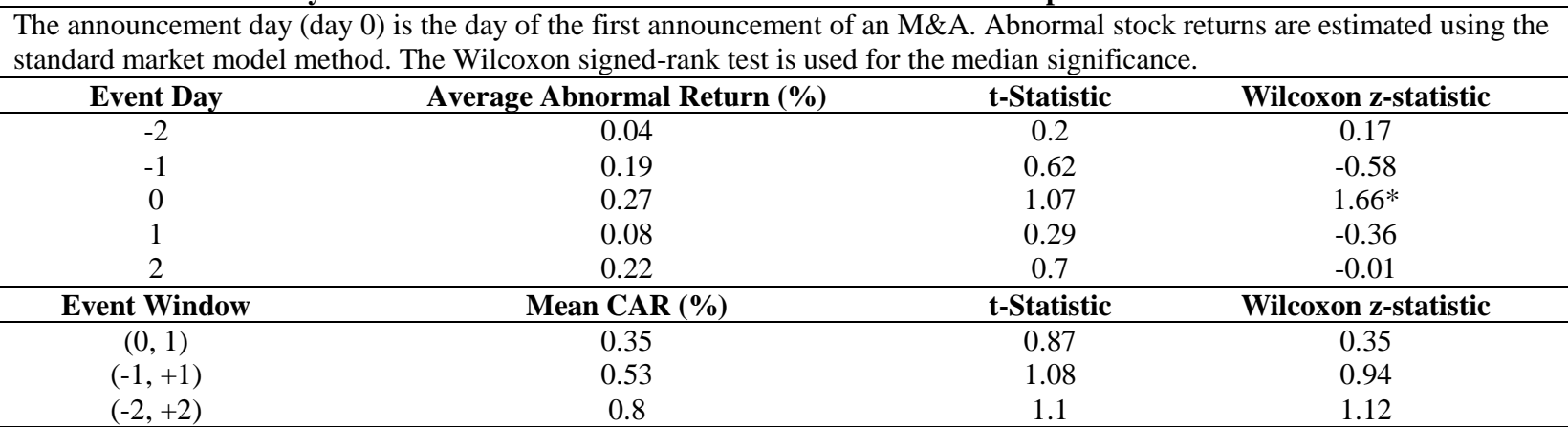

The symbols * denote statistical significance at the $10 \%$ levels.

Table 5 indicates that stock markets have a positive response to bidding firms when transactions are specifying acquisitions. The mean value of the two-day CAR for specifying M\&A deals in the banking industry is $0.74 \%$, which is not statistically significant. Analysis of three-day CAR generates the similar results. Therefore, hypothesis $\mathrm{H} 2$ (that there is no abnormal return associated with specifying M\&A in the banking industry around the M\&A announcement) is supported. This finding implies that economies of scale for the Asian banking industry do not increase shareholders wealth.

The mean value of the two-day CAR for diversifying banks M\&A is $0.1 \%(=0.74-0.64)$ and the mean value of the three-day CAR is $0.71 \%(=0.25+0.46)$. These results indicate that stock markets have positive responses to bidding firms when transactions are diversifying M\&A deals. The differences between the CARs of specifying M\&A deals and the CAR of diversifying M\&A deals are not statistically significant. The overall conclusion is that statistically the mean values of two-day and three-day CAR for specifying M\&A and diversifying M\&A are about the same and statistically insignificant from zero. Thus, Hypothesis H3 (that there is a positive valuation effect associated with a diversifying bank M\&A around merger announcements) is rejected. It implies that the diversification of banks does not significantly increase shareholders wealth. 
Table 5: Results of regression analysis on mean value differences

The model, $\mathrm{CAR}=\beta_{0}+\beta_{1} * \mathrm{MA}_{\mathrm{Cross}}+\mathrm{e}$, is used to examine the stock market response to the specifying M\&A and diversifying M\&A. CAR is the cumulative abnormal return within two-day $(0,+1)$ or three-day $(-1,+1)$ or window. MA is a categorical variable, defined as the strategy (e.g., specifying and diversifying) used by the firm. $\mathrm{MA}_{\text {Cross }}=1$ if it is diversifying mergers, zero otherwise.

\begin{tabular}{lcccccc}
\hline \multirow{2}{*}{ Variable } & \multicolumn{3}{c}{ CAR $(\mathbf{0},+\mathbf{1})$} & \multicolumn{3}{c}{ CAR (-1, +1) } \\
\cline { 2 - 7 } & Coeff. & Std. Error & $\mathrm{t}$ & Coeff. & Std. Error & t \\
\hline INTERCEPT & 0.74 & 0.77 & 0.96 & 0.25 & 0.3 & 0.66 \\
MA $_{\text {Cross }}$ & -0.64 & 0.89 & -0.72 & 0.46 & 0.45 & 0.76 \\
\hline
\end{tabular}

Table 6 indicates that there are no significant firm size effects on both the two-day window and the threeday window. When using the logarithm value of total assets to represent a firm size in the proposed model (1), estimates of the coefficients for the firm size variable have negative sign on the two windows. Therefore, H4 (that there is a significant valuation effect associated with the firm size of the acquirer when a banking M\&A occurs) is rejected. After controlling for the size of the bidding firm, the estimate (i.e., constant value $\beta_{0}$ ) of specifying M\&A deals in the two-day window becomes 5.07 (from 0.74). The estimate of specifying M\&A deals in the three-day window becomes 4.81 (from 0.25 ). The estimate $\left(\beta_{1}\right)$ of diversifying M\&A deals is lower by 0.58 percentage points than specifying M\&A deals in the two-day window. The three-day mean CAR of diversifying M\&A deals is 0.51 percentage points higher than that of focusing M\&A deals. The firm size variable has the expected negative sign, which implies that large firms have less pronounced market reactions.

Table 6: Results of regression analysis controlling for firm size

The model, CAR $=\beta_{0}+\beta_{1} * \mathrm{MA}_{\text {Cross }}+\beta_{2}{ }^{*} \mathrm{SIZE}+\mathrm{e}$, is used to examine the stock market responses to the specifying bank M\&A and diversifying bank M\&A. CAR is the cumulative abnormal return within two- day $(0,+1)$ or three-day $(-1,+1)$ window. SIZE is log-transformation of total assets of acquirer at the time of M\&A announcement. MA is a categorical variable. MA $\mathrm{A}_{\mathrm{Cross}}$ $=1$ if it is diversifying mergers, zero otherwise.

\begin{tabular}{lcccccc}
\hline \multirow{2}{*}{ Variable } & \multicolumn{3}{c}{ CAR $(\mathbf{0},+\mathbf{1})$} & \multicolumn{3}{c}{ CAR $\mathbf{( - 1 , + 1 )}$} \\
\cline { 2 - 7 } & Coeff. & Std. Error & $\mathrm{t}$ & Coeff. & Std. Error & t \\
\hline INTERCEPT & 5.07 & 4.13 & 1.23 & 4.81 & 4.97 & 0.97 \\
MA $_{\text {Cross }}$ & -0.58 & 0.88 & -0.67 & 0.51 & 1.03 & 0.49 \\
SIZE & -0.46 & 0.41 & -1.13 & -0.48 & 0.49 & -0.99 \\
\hline
\end{tabular}

\section{SUMMARY}

Through analysis of stock responses to two different types of banking M\&A deals, specifying M\&A and diversifying $\mathrm{M} \& \mathrm{~A}$, we find that specifying $\mathrm{M} \& \mathrm{~A}$ deals incur positive cumulative abnormal returns in both two-day and three-day windows without controlling for firm size. Diversifying M\&A deals incur positive CAR in two different event windows. However, the differences are not statistically significant. Contrary to previous studies on M\&A in the banking industry of developed markets (Delong, 2001; Lepetit et al. 2004), the results of our study indicate that markets do not distinguish among various types of M\&A deals in the banking industry around the date of announcement. Diversifying M\&A generate positive three-day CARs but they are not significantly better than specifying M\&A. The synergy hypothesis (or focused strategy) is not supported in Asian developing markets. Our study on the banking industry M\&A partially support the internal capital market theory. This theory encourages diversifying M\&A deals because diversifying M\&A deals incur a positive (but not statistically significant) CAR.

For banking M\&A deals, we find that the firm size variable has the expected negative sign but is not statistically significant. The negative sign of the firm size variable indicates that larger firms tend to generate smaller abnormal returns. The significant effect is less likely to be detected probably due to the small sample size.

The findings of this study have important implications. First, researchers should separate the banking industry M\&A data from non-financial industries M\&A data when conducting M\&A research in Asian developing markets. Second, Asian developing markets' reaction is less pronounced to the banking industry's M\&A deals than to the non-banking industries' M\&A deals. Third, our findings are consistent with the view that the acquiring banks tend to gain on the forced merger scheme (Chong et al. 2006). 


\section{AUTHOR INFORMATION}

Jianyu Ma received his PhD in Finance and Business Administration from the University of Texas - Pan American. $\mathrm{He}$ is an Assistant Professor in the Department of Finance at the Robert Morris University. His current research interests include high-technology performance evaluation, international investment and mergers and acquisitions. E-mail: ma@rmu.edu. Corresponding author.

José A. Pagán is a Professor and Chair of the Department of Health Management and Policy, School of Public Health, University of North Texas Health Science Center at Fort Worth. Also, he is an Adjunct Senior Fellow of the Leonard Davis Institute of Health Economics at the University of Pennsylvania. He received his $\mathrm{PhD}$ in Economics in 1995 from the University of New Mexico. E-mail: jpagan@hsc.unt.edu

Yun Chu received her PhD in Marketing and International Business from the University of Texas - Pan American. She is an Associate Professor in the Department of Marketing at the Robert Morris University. Her research interests include consumer behavior, international marketing, nonverbal communications in cross-cultural business negotiations and customer relationship management. E-mail: chu@rmu.edu

\section{REFERENCES}

1. Berger, P. G., \& Ofek, E. (1995). Diversification's effect on firm value. Journal of Financial Economics, 37(1), 39-65.

2. Berk, J. B. (1995). A critique of size-related anomalies. The Review of Financial Studies, 8(2), 275-286.

3. Brown, S. J., \& Warner, J. B. (1985). Using daily stock returns: The case of event studies. Journal of Financial Economics, 14(1), 3-31.

4. Chong, B.-S., Liu, M.-H., \& Tan, K.-H. (2006). The wealth effect of forced bank mergers and cronyism. Journal of Banking and Finance, 30, 3215-3233.

5. $\quad$ Claessens, S., Djankov, S., Fan, J. P. H., \& Lang, L. H. P. (1999). The rationale for groups: Evidence from East Asia. Unpublished manuscript, World Bank.

6. Cornett, M. M., \& Tehranian, H. (1992). Changes in corporate performance associated with bank acquisitions. Journal of Financial Economics, 31(2), 211-234.

7. Crouzille, C., Lepetit, L., \& Bautista, C. (2006). How did the Asian stock markets react to bank mergers after the 1997 financial crisis? Pacific Economic Review, 13(2), 211-234.

8. Cybo-Ottone, A., \& Murgia, M. (2000). Mergers and shareholder wealth in European banking. Journal of Banking and Finance, 24(6), 831-859.

9. Delong, G. (2001). Stockholder gains from focusing versus diversifying bank mergers. Journal of Financial Economics, 59(2), 221-252.

10. Delong, G. (2003). Does long-term performance of mergers match market expectations? Evidence from the U.S. banking industry. Financial Management, 32(2), 5-25.

11. Dymski, G. (2002). The global bank merger wave: Implications for developing countries. The Developing Economies, 40(4), 435-466.

12. Fraser, D. R., Gup, B. E., \& Kolari, J. W. (2001). Commercial banking: The management of risk. Cincinnati, OH: South-Western College Publishing.

13. Gelos, G., \& Roldos, J. (2004). Consolidation and market structure in emerging market banking systems. Emerging Market Review, 5(1), 39-59.

14. Hawawini, G., \& Swary, I. (1990). Mergers and acquisitions in the U.S. Banking industry: Evidence from the capital market. Journal of Economic Literature, 30(2), 911-912.

15. Hawkins, J., \& Mihaljek, D. (2001). The banking industry in the emerging market economies: Competition, consolidation and systemic stability-An overview (No. 4). Bank for International Settlement (BIS) paper.

16. Hawkins, J., \& Turner, P. (1999). Bank restructuring in practice: An overview (No. 6). Bank for International Settlement (BIS) Policy Paper.

17. Houston, J., James, C., \& Ryngaert, M. (2001). Where do merger gains comes from? Bank mergers from the perspective of insiders and outsiders. Journal of Financial Economics, 60(2-3), 285-331.

18. Hubbard, R. G., \& Palia, D. (1999). A reexamination of the conglomerate merger wave in the 1960s: An internal capital markets view. The Journal of Finance, 54(3), 1131-1152. 
19. Jackson, D., \& Madura, J. (2004). Bank profit warnings and signaling. Managerial Finance, 30(9), 20-31.

20. Lang, L. H. P., \& Stultz, R. (1994). Tobin's q, corporate diversification, and firm performance. The Journal of Political Economy, 102(6), 1248-1280.

21. Lepetit, L., Patry, S., \& Rous, P. (2004). Diversification versus specification: An event study of M\&As in the European banking industry. Applied Financial Economics, 14(9), 663-669.

22. Lins, K., \& Servaes, H. (2002). Is corporate diversification beneficial in emerging markets? Financial Management, 31(2), 5-31.

23. Nicolo, G. D., Bartholomew, P., Zaman, J., \& Zephirin, M. (2003). Bank consolidation, internationalization, and conglomeration: Trends and implications for financial risk. Retrieved July 28, 2007, from http://ssrn.com/abstract=879234.

24. Piloff, S. (1996). Performance changes and shareholder wealth creation associated with mergers of publicly trading banking institutions. Journal of Money, Credit and Banking, 28(3), 294-310.

25. Piloff, S., \& Santomero, A. (1997). The value effects of bank mergers and acquisitions. Philadelphia: University of Pennsylvania, Wharton School Center for Financial Institutions.

26. Schwert, G. W. (1983). Size and stock returns, and other empirical regularities. Journal of Financial Economics, 12(1), 3-12.

27. Shin, H., \& Stulz, R. (1988). Are internal capital markets efficient? Quarterly Journal of Economics, 113(2), 531-552.

28. Stein, J. (1997). Internal capital markets and the competition for corporate resources. The Journal of Finance, 52(1), 111-134.

29. Zhang, H. (1995). Wealth effects of US bank takeovers. Applied Financial Economics, 5(5), 329-336. 
NOTES 